\title{
The effect of aluminum oxide sandblasting and discs on shear bond strength of metal
}

\section{brackets rebonded in eroded enamel}

\author{
Efeito da aplicação do microjateamento de óxido de alumínio e discos de óxido de alumínio na \\ resistência adesiva de braquetes metálicos recolados em esmalte previamente erodido \\ El efecto de granallado y discos de óxido de aluminio en la resistencia adhesiva a la cizalladura de \\ brackets metálicos adheridos nuevamente en esmalte erosionado
}

Received: 09/01/2021 | Reviewed: 09/10/2021 | Accept: 10/01/2021| Published: 10/03/2021

Luciana de Vasconcelos Leão

ORCID: https://orcid.org/0000-0001-7499-0068

Federal University of Sergipe, Brazil

E-mail: lucianavleao@yahoo.com.br

Adriana Oliveira

ORCID: https://orcid.org/0000-0002-7456-3784

Federal University of Sergipe, Brazil

E-mail: adrii.olliveira@gmail.com

Jefferson Chaves Moreira

ORCID: https://orcid.org/0000-0003-4276-4810

São Paulo State University, Brazil

E-mail: chaves.moreira@unesp.br

Luiz Renato Paranhos

ORCID: https://orcid.org/0000-0002-7599-0120

Federal University of Uberlândia, Brazil

E-mail: paranhos@ortodontista.com.br

Sigmar de Mello Rode

ORCID: https://orcid.org/0000-0002-4261-4217

São Paulo State University, Brazil

E-mail: sigmar.rode@unesp.br

Flavia Pardo Salata Nahsan

ORCID: https://orcid.org/0000-0002-3547-8886

Federal University of Sergipe, Brazil

E-mail: flavia_odonto@ hotmail.com

\begin{abstract}
This research aimed to assess the effect of aluminum oxide sandblasting and discs on the bond strength of metal brackets rebonded on artificially eroded enamel. Fifty-four bovine incisors were divided into groups: Control (Artificial Saliva), AlOx (Aluminum oxide sandblasting), and SL (Aluminum oxide discs). They had their enamel surface flattened with Al2O3 discs and a metallographic polisher, then Knoop microhardness was assessed. AlOx and SL specimens were eroded with Coca-Cola ${ }^{\mathrm{TM}}$ for 1 minute, 3 times a day for 7 days. Metal brackets were bonded to the tooth. Shear strength was measured by an EMIC universal testing machine $(0.5 \mathrm{~mm} / \mathrm{min})$. The Adhesive Remnant Index (ARI) was performed after shearing through magnifying glass (10X). Kolmogorov-Smirnov, Levene, homoscedasticity and ANOVA tests were applied to assess microhardness and shear strength $(\mathrm{p}=0.163)$. All groups presented shear bond strength with no significant differences. The ARI showed statistically significant difference between the groups. The prevalence for the control group was ARI 3. However for AlOx and SL, ARI 1 and 2 prevailed. The aluminum oxide sandblasting and aluminum oxide discs did not positively increase the bond strength of brackets when bonded to artificially eroded enamel. The ARI indicated that eroded teeth present higher resin adhesion to enamel.
\end{abstract}

Keywords: Shear bond strenght; Orthodontics; Dental erosion.

\section{Resumo}

O objetivo foi avaliar o efeito da aplicação do microjateamento de óxido de alumínio e de discos de óxido de alumínio na resistência adesiva de braquetes metálicos recolados em esmalte erodido artificialmente. 54 coroas de incisivos bovinos foram divididas em função dos grupos: Controle (Saliva Artificial), Ox Al (Microjateamento com óxido de alumínio) e SL (discos de óxido de alumínio). Eles tiveram sua superfície de esmalte aplainada e a microdureza Knoop foi avaliada. Após aferição os dentes de OxAl e SL foram submetidos ao desafio erosivo, submersos em CocaCola ${ }^{\circledR}$ por 1 minuto, $3 \mathrm{X}$ ao dia, por 7 dias. Foram colados braquetes metálicos nos dentes. A força de cisalhamento 
foi mensurada por meio de uma máquina de teste universal EMIC $(0,5 \mathrm{~mm} / \mathrm{min})$. O Índice de Remanescente Adesivo (IRA) foi obtido nas amostras utilizando-se lupa (10X). Foram aplicados os testes de Kolmogorv-Smirnov, de Levene e a homocedasticidade e ANOVA para avaliação da microdureza e força de cisalhamento. Não houve diferenças estatisticamente significantes entre os grupos quando avaliadas microdureza $(p=0,163)$. Porém, ao avaliar o IRA, houve diferença estatisticamente significativa ao comparar o grupo Controle com o OxAl e SL. Sendo a prevalência de IRA 3 para o grupo controle. Para OxAl e SL, IRA 1 e 2 prevaleceram. Concluiu-se que o uso de microjateamento de óxido de alumínio e discos de óxido de alumínio não aumentaram a resistência adesiva dos braquetes quando colados em esmalte erodido artificialmente. O índice de remanescente adesivo indicou que dentes erodidos apresentam uma maior adesão da resina ao esmalte.

Palavras-chave: Resistência ao cisalhamento; Ortodontia; Erosão dentária.

\section{Resumen}

El objetivo de esta investigación fue evaluar el efecto de granallado y discos de óxido de aluminio en la resistencia adhesiva a la cizalladura de brackets metálicos adheridos nuevamente en esmalte artificialmente erosionado. Cincuenta y cuatro incisivos bovinos fueron divididos en los grupos: De control (Saliva Artificial), AlOx (Granallado de óxido de aluminio), y SL (Discos de óxido de aluminio). Las superficies de esmalte fueron aplanadas con discos de Al2O3 y con un pulidor metalográfico, luego después la Microdureza de Knoop fue evaluada. Los especímenes de AlOx y SL fueron erosionados con Coca-Cola ${ }^{\mathrm{TM}}$ por 1 minuto, 3 veces al día durante 7 días. Brackets de metal fueron adheridos en el diente. Se midió la resistencia a la cizalladura por una máquina de ensayo universal EMIC (0.5 $\mathrm{mm} / \mathrm{min}$ ). Fue hecho el Índice de Residuos Adhesivos (IRA) a través de lupa (10X). Fueron aplicados tests de Kolmogorov-Smirnov, Levene, homocedasticidad y ANOVA para evaluar la microdureza y resistencia adhesiva $(\mathrm{p}=0.163)$. Niguno de los grupos present diferencia estadísticamente significativa de resistencia adhesiva a la cizalladura. El ARI mostró diferencia estadísticamente significativa entre las agrupaciones. La prevalencia fue de IRA 3 para el grupo De Control. Sin embargo, para AlOx y SL, IRA 1 y 2 prevalecieron. El granallado de óxido de aluminio y los discos de óxido de aluminio no aumentaron la resistencia de brackets adheridos a esmaltes artificialmente erosionados. El IRA señaló que dientes erosionados presentaron mayor adhesión de resina al esmalte.

Palabras clave: Resistencia adhesiva a la cizalladura; Ortodoncia; Erosión dental.

\section{Introduction}

Tooth wear has presented a significant prevalence increase over the last years because of the high consumption of acidic beverages such as sports drinks, fruit juices, and industrialized teas, which have the potential to cause enamel demineralization (Deery, Wagner, Longbottom, Simon \& Nugent, 2000; Federlin, Thonemann, Schmaiz \& Urlinger, 1998; Meira et al., 2021). Cola drinks, for being highly consumed, are considered one of the main extrinsic etiological factors (Ganss, Klimek \& Giese, 2001).

Erosion is the loss of superficial dental structure because of a chemical action, with no involvement of microorganisms, characterizing a demineralization process that weakens enamel surface with subsequent wear, which may affect dentin (Meurman \& Ten Cate, 1996; Lussi, Jaeggi \& Zero, 2004). The compromise of enamel will also depend on etiological agent and exposure intensity (Magalhães, Wiegand, Rios, Honório \& Buzalaf, 2009).

Adhesion to sound enamel is effective, simple, and safe (Pashley et al., 2011), especially when compared to adhesion to dentin. The use of orthodontic brackets directly on sound enamel is a constant clinical practice, but the presence of a sound enamel in ideal conditions for adhesion is not always established (Mine et al., 2010), considering that ionic exchanges, chemical and mechanical challenges, and changes related to the individual and the dynamic environment that is the oral cavity constantly occur (Tavares et al., 2003).

Regardless of the type of enamel available in the routine of orthodontic practice, the rebonding of metal brackets is a reality for being considered a viable and economic option (Yassaei, Aghili, Khanpayeh \& Goldani Moghadam, 2014; Reddy, Varma, Kumar, Kumar \& Shetty, 2011). Brackets may be recycled by being sent to a specialized industrial treatment or directly at the dental office (Montero, Vicente, Alfonso-Hernández, Jiménez-López \& Bravo-Gozález, 2015). Some studies assessed the potential options for removing adhesive remnants from debonded brackets, among which are thermal methods (laser, direct flame (Basudan \& AI-Emran, 2001), or the Buchmann method (Buchman, 1980)), mechanical ones sandblasting 
(Basudan et al., 2001), green stone (Basudan et al., 2001), and carbide bur (Eminkahyagil, Arman, Cetinsahin \& Karabulut, 2006) or chemical ones (acid bath solution (Gupta, Kumar \& Palla, 2017)).

However, despite the aforementioned problem, up to now studies have been limited to assessing the bond strength of brackets, as well as their rebonding on sound enamel (Ahrari, Fekrazad, Katavoun \& Ramtin, 2013). Because erosion causes changes in enamel, the interaction and aspects related to failure and rebonding of brackets on eroded enamel, as well as treatment alternatives, should be investigated.

Facing this problem, this study aimed to assess the effect of different treatments at the base of brackets, aluminum oxide sandblasting, and aluminum oxide discs (Sof-Lex Pop On, 3M ESPE) on bond strength of enamel artificially eroded with Coca-Cola ${ }^{\mathrm{TM}}$. The null hypotheses are that the use of sandblasting and discs have no influence on the adhesion of metal brackets rebonded on eroded teeth.

\section{Methodology}

\section{Teeth selection}

This quantitative experimental in vitro study (Pereira, Shitsuka, Parreira \& Shitsuka, 2018) selected 54 bovine incisors with no fractures or crown cracks detected in the direct visual inspection and stored in saline solution at room temperature. The teeth were divided into 3 groups (C-Control, AlOx- Aluminum oxide sandblasting, and SL- Sof-Lex aluminum oxide disc).

\section{Sample Calculation}

For sample calculation, the mean standard deviation of 5.6 Mpa found by Eminkahyagil, Arman, Cetinsahin and Karabulut (2006) was used. By applying 5\% significance level and 80\% test power to detect a minimal difference of 6 Mpa among the groups, at least 18 specimens per group were required.

\section{Sample preparation}

The roots were sectioned in the cementoenamel junction and the crowns were placed in polyvinyl chloride (PVC) cylinders, secured at the lingual aspect with self-polymerizing acrylic resin.

Teeth were cut to flatten the dental enamel, so shear strength would be applied parallel to the enamel surface. Cutting was made by a low-speed machine and two diamond discs (Extec Corp., Enfield, CT, USA) separated by a 4-mm thick spacer. The enamel surface was flattened by carborundum discs (\#320, 600, and $1200 \mathrm{Al}_{2} \mathrm{O}_{3}$ discs; Buehler, Lake Bluff, IL, USA), which resulted in the removal of approximately $100 \mu \mathrm{m}$ of depth. Polishing was performed with felt paper wet by diamond spray with a metallographic polisher of multiple system able to automatically polish 6 specimens (APL4, Arotec, Cotia, SP, Brazil).

\section{Microhardness}

In order to standardize enamel surfaces, a Knoop microhardness test was performed by testing 3 indentations in different points of the enamel, with load of $25 \mathrm{~g}$ and time of $5 \mathrm{~s}$ (HMV-2000; Shimadzu Corporation, Tokyo, Japan). The enamel blocks that presented microhardness between 260 and $320 \mathrm{KHN}$ were included in the sample.

\section{Groups}

Teeth were randomly divided into 3 groups according to treatment on enamel and metal bracket base: Control (C) Artificial saliva and untreated bracket, Erosion with Coca Cola ${ }^{\mathrm{TM}}+$ Aluminum oxide sandblasting (AlOx), and Erosion with Coca Cola ${ }^{\mathrm{TM}}+$ Sof-Lex Pop On disc (SL). 


\section{Erosive challenge and adhesion of brackets}

Teeth were subjected to their respective acid mediums for 1 minute, 3 times a day for 7 days (Rios D, 2004).

For bracket bonding, an acid attack was performed with 37\% phosphoric acid on enamel, for 15 seconds, abundant wash for 30 seconds, and dried by air blast. The Transbond ${ }^{\mathrm{TM}}$ XT adhesive (3M Unitek, Landsberg, Germany) was applied and light-cured for 20 seconds with the Radii-cal device (SDI, Victoria, Australia). Next, the stainless steel metal orthodontic bracket, Roth prescription (3M/Abzil, São José do Rio Preto, São Paulo, Brazil) designed for upper right central incisors, slot 022 was bonded with Transbond ${ }^{\mathrm{TM}}$ XT resin (3M Unitek, Landsberg, Germany), whereas 5 seconds were applied by the mesial aspect and 5 seconds by the distal aspect, according to manufacturer's instructions.

\section{Shearing}

Specimens were stored in artificial saliva and later subjected to shear strength, in a universal testing machine (DL200, EMIC, São José dos Pinhais, Paraná, Brazil) at speed of $0.5 \mathrm{~mm} / \mathrm{min}$. The samples were placed at the base of the equipment and a chisel was placed parallel to the long axis of the tooth, on the tooth/bracket interface, with $0.5 \mathrm{~mm}$ of plate thickness.

\section{Teeth preparation}

The teeth presenting adhesive remnants in their surfaces were treated with aluminum oxide discs of medium granulation, until complete removal.

\section{Bracket preparation and rebonding}

The brackets of the control group were not treated and new brackets were rebonded. In the AlOx group, the brackets were sandblasted (Renfert, Germany) with $50 \mu \mathrm{m}$ of aluminum oxide particles at $75 \mathrm{psi}$ for 4 seconds, at a 10-mm distance. In the SL group, the brackets were treated with Sof-Lex Pop On aluminum oxide discs (3M ESPE) with medium and thin granulations on each bracket and mild pressure, for 10 seconds each disc.

Again, enamel was conditioned with 37\% phosphoric acid and the recycled brackets were rebonded, following the same steps for bonding so that shear strength would be measured in this new condition. Specimens were stored for $24 \mathrm{~h}$ and a new shear test was performed.

\section{Adhesive Remnant Index (ARI)}

Next, the enamel of all specimens was assessed by a calibrated investigator with a 10X magnifying glass to determine the Adhesive Remnant Index (ARI), according to the following scores proposed by Talbot et al. (2000): 1- all resin remained on the enamel, 2- over $90 \%$ of resin remained on the enamel, 3- more than $10 \%$ and less than $90 \%$ of resin remained on the enamel, 4- less than $10 \%$ of resin remained on the enamel, and 5- no resin remained on the enamel.

\section{Statistical analysis}

Data were described by the parameters of mean and standard deviation. To verify whether the groups presented normal distribution, the Kolmogorov-Smirnov test was used, and no group showed a significant deviation from normality.

To verify whether there was homogeneity of variance (homoscedasticity) among the groups, the Levene test was used, and homoscedasticity ( $\mathrm{p}=0.090$ for strength and $\mathrm{p}=0.570$ for microhardness) was proved.

For the comparison among the three groups, the fixed-model Analysis of Variance (ANOVA) was used. For the comparison among the three groups regarding ARI, the Friedman non-parametric test was used. 
All statistical procedures were performed in the Statistica software (StatSoft Inc., Tulsa, USA) version 13.

\section{Results}

There was no statistically significant difference among the three groups studied $(\mathrm{p}=0.110)$ regarding microhardness. The control group (C) presented higher microhardness mean when compared to the AlOx and SL groups, which were subjected to the erosive challenge with acidic beverage (Table 1 and Graph 1).

Table 1 - Mean, standard deviation of microhardness of specimens, and ANOVA results for the comparison among the three groups.

\begin{tabular}{llll}
\hline Group & mean & sd & $\mathrm{p}$ \\
\hline Control & 305.71 & 60.90 & \\
AlOx & 262.70 & 69.23 & $0.110 \mathrm{~ns}$ \\
SL & 299.11 & 63.84 & \\
\hline
\end{tabular}

$\mathrm{ns}-$ not statistically significant difference $(\mathrm{p}>0.05)$. Source: Authors.

Graph 1 - Mean and standard deviation of microhardness of the three groups.

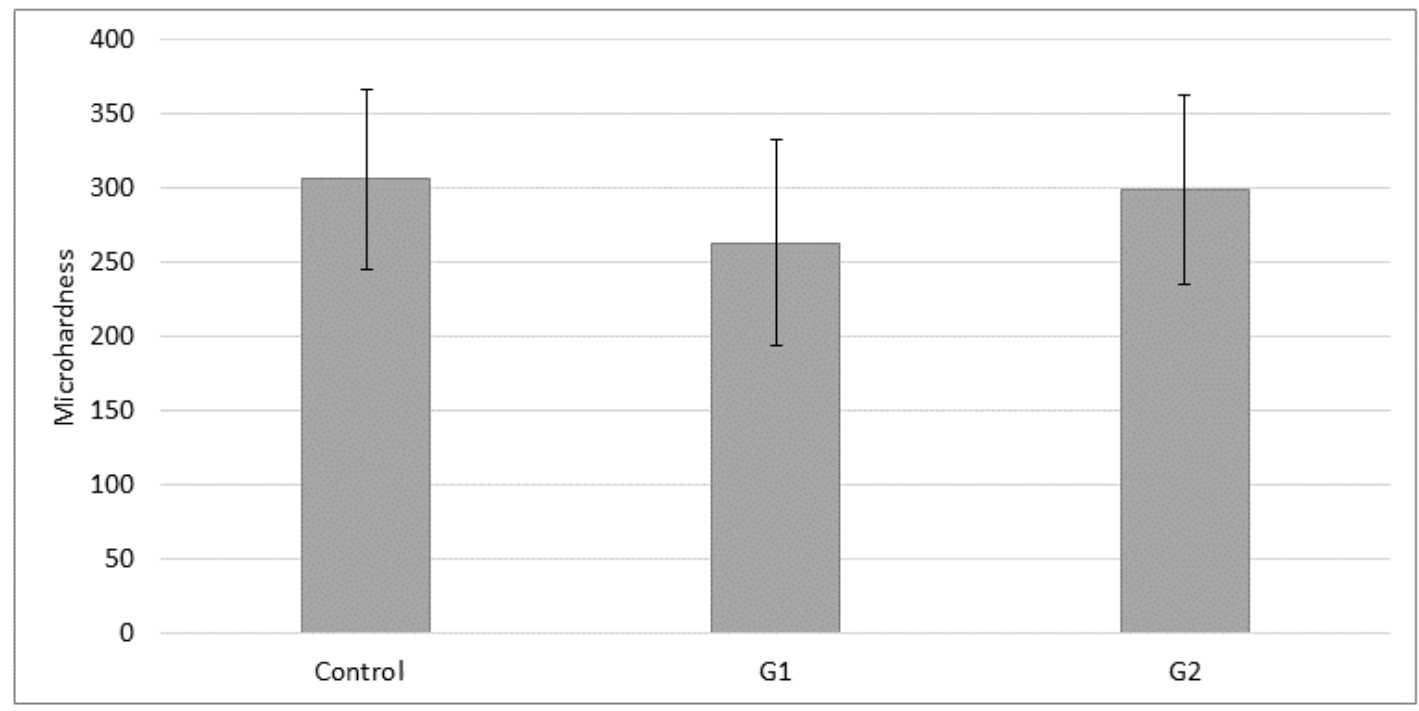

Source: Authors.

There was no statistically significant difference regarding shear bond strength among the three groups (Table 2 and Graph 2). However, a higher mean was observed for AlOx, where brackets were treated with aluminum oxide sandblasting. 
Table 2 - Mean, standard deviation, minimum and maximum strength (Mpa) of specimens, and ANOVA results for the comparison among the three groups.

\begin{tabular}{llllll}
\hline Group & mean & sd & minimum & maximum & $\mathrm{p}$ \\
\hline Control & 14.99 & 5.40 & 7.79 & 25.36 & \\
AlOx & 16.15 & 3.80 & 8.93 & 23.41 & $0.163 \mathrm{~ns}$ \\
SL & 13.32 & 3.80 & 6.77 & 21.71 & \\
\hline
\end{tabular}

ns - not statistically significant difference ( $p>0.05)$. Source: Authors.

Graph 2 - Mean and standard deviation of strength of the three groups.

25

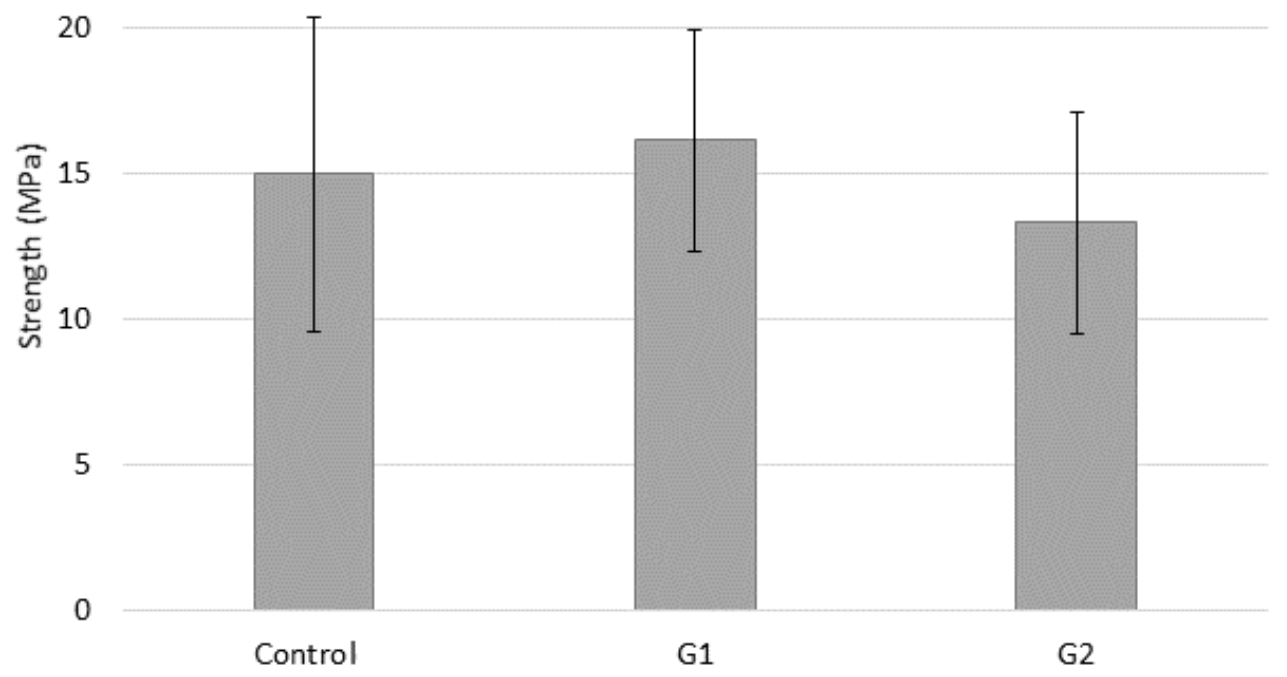

Source: Authors.

The ARI assessment of groups showed a statistically significant difference when comparing the control group to AlOx and SL groups. The prevalence for the control group was ARI 3 (50\%), followed by ARI 4 (22\%) and 5 (22\%).

For AlOx and SL, ARI 1 and 2 prevailed, but there were no differences between both these groups (Table 3). 
Table 3 - Comparison among the three groups regarding ARI.

\begin{tabular}{|c|c|c|c|c|c|c|c|c|c|c|}
\hline \multirow{2}{*}{ Group } & $\begin{array}{l}\text { ARI } \\
\text { score }\end{array}$ & $\begin{array}{l}\text { Median } \\
\text { score }\end{array}$ & \multicolumn{2}{|l|}{$\mathrm{p}$} & \multirow[b]{2}{*}{5} & & & & & \\
\hline & 1 & 2 & 3 & 4 & & & & & & \\
\hline Control $^{\mathrm{a}}$ & $6 \%$ & $0 \%$ & $50 \%$ & $22 \%$ & $22 \%$ & 3 & & & & \\
\hline $\mathrm{AlOx}^{\mathrm{b}}$ & $33 \%$ & $33 \%$ & $28 \%$ & $0 \%$ & $6 \%$ & 2 & $<0.001 *$ & & $\neq$ & \\
\hline $\mathrm{SL}^{\mathrm{b}}$ & $67 \%$ & $22 \%$ & $11 \%$ & $0 \%$ & $0 \%$ & 1 & & & & \\
\hline
\end{tabular}

* - statistically significant difference ( $\mathrm{p}<0.05)$. Friedman non-parametric test. Source: Authors.

\section{Discussion}

This research aimed to assess the effect of aluminum oxide sandblasting and aluminum oxide discs on the bond strength of brackets rebonded on artificially eroded enamel. The results presented no statistically significant differences for shear bond strength among the groups, corroborating data found in the study by Tavares et al. (2006). The Adhesive Remnant Index indicated that eroded teeth present higher resin adhesion to enamel. Thus, the first null hypothesis should be accepted and the second one rejected.

However, among the recycling methods employed, the higher mean was observed in the AlOx group, where brackets were treated with aluminum oxide sandblasting, agreeing with the study by Yassaei et al. (2014) and Gupta et al. (2017), in which brackets treated with sandblasting presented higher shear values. These results prove that sandblasting and the use of low-rotation carbide burs and ultrasonic tips can remove adhesive remnants from brackets and leave them to be reused with bond strengths similar to that of new brackets (Al Maaitah, Alomari, Abu Alhaija \& Saf, 2013). Aluminum oxide sandblasting has been shown as a good option for recycling brackets (Anita \& Kailasam, 2021), because its technical handling is easy and it may be performed in the dental office, which reduces time and financial costs (Tavares et al., 2006; Gupta et al., 2017).

The results of this study showed that recycling brackets with aluminum oxide sandblasting provided higher mean shear strength (16.15 Mpa) when compared to the control group (14.99 Mpa) and the group recycled with Sof-Lex discs (13.32 Mpa). Nevertheless, the Adhesive Remnant Index showed that adhesion to eroded enamel was higher than to non-eroded enamel (control). This may be explained by the demineralization mechanism, where hydrogen ions are released by the acid substances and connect to the carbonate or phosphate ions of the dental structure, or the action of anions that connect to calcium and form other complexes (Barbour, Parker, Allen \& Jandt, 2005). Thus, hydroxyapatite is lost to the medium, disrupting the enamel and causing wear (Wang \& Lussi, 2010). This wear may have generated a rougher surface and consequently higher resin adhesion to enamel.

Several methods for removing adhesive remnants from debonded brackets have already been researched (Basudan $e t$ al., 2001; Buchman et al., 1980; Eminkahyagil et al., 2006; Gupta et al., 2017), but there is not much information about aluminum oxide discs, and this study was designed because these methods are accessible and feasible for the dental office. However, the results presented no positive influence of the use of discs on bond strength of recycled brackets. The resin inside the metal mesh of the bracket may not have been completely removed.

The shear strength of new and recycled brackets has been the object of study interest among orthodontists. This strength may vary according to the testing method (Katona \& Long, 2006). A study showed that the variation on chisel speed 
between 0.1 and $5 \mathrm{~mm} / \mathrm{min}$ has no significant influence on shear strength (Klocke \& Kahl-Nieke, 2005). In this study, the lowering speed of the chisel was $0.5 \mathrm{~mm} / \mathrm{min}$ during the test.

Pasha et al. (2015) and Gupta et al. (2017), found that the higher shear bond strength occurred in the control group. On the other hand, groups AlOx and SL, which were subjected to the erosive challenge with acidic beverage, presented lower shear bond strength values, corroborating with Oncag, Tuncer and Tosun (2005) study that verified the influence of acidic beverages on the bond strength of brackets and showed a significant reduction of bond strength upon exposure to these types of beverages. This may be justified by the fact that these beverages could have two concomitant effects on bond strength of orthodontic brackets: directly deteriorating the structure of adhesive materials and causing erosive lesions on enamel surface around the orthodontic accessories, consequently decreasing bond strength (Pasha et al.,2015).

One of the prerequisites to ensure the bonding of orthodontic brackets with satisfactory retention is the presence of a sound enamel surface, whereas failure occurs in the case of alteration (Mitchell, 1992). The enamel of dental surfaces presents in the oral cavity of individuals who went through dental erosion is presented as an altered substrate (Tavares et al., 2006). The erosion of dental enamel has been indicated as one of the causes of bonding failure because it results from the loss of mineral components of teeth by the exposure to a variety of acids (Hall et al., 1999), in which the chemical process does not involve bacteria participation. Regarding the previously eroded substrate, there are still few reports about its implications on restorative procedures, especially regarding the adhesion of restorative material (Tavares et al., 2006), and further details are required for these changes related to bonding (Casas-Apayco et al., 2014).

The high consumption of acidic beverages, Coca-Cola ${ }^{\mathrm{TM}}$ among them, draws the attention of researchers. A study performed by Gedalia in 1991 verified the softening of dental enamel after 1 hour of contact with the soft drink Coca-Cola ${ }^{\mathrm{TM}}$. Another research (Magalhães et al., 2009) concluded that cola drinks cause the loss of surface hardness, and the soft drink Coca-Cola ${ }^{\mathrm{TM}}$ reduces bond strength, regardless of the type of Coca-Cola ${ }^{\mathrm{TM}}$ - regular, light, or zero (Gedalia, 1991). In another study by Oncag et al. (2005), the authors claim that the defect areas on enamel caused by the erosive effect of Coca-Cola ${ }^{\mathrm{TM}}$ and Sprite have a negative effect in bracket retention.

Initial surface microhardness was performed aiming to standardize the specimens that would be subjected to erosion, bonding, and rebonding of brackets. Thus, the present study allows specimens to be relatively equal for being subjected to the same acidic conditions, and provides conditions for the results found to be compared to the control group (Gedalia, 1991).

In vitro studies play an important role for improving techniques and materials, and simulate situations that may not be assessed clinically (Moura, Carmo \& Tavano, 2020). The scientific literature, however, is scarce in studies assessing bracket recycling on eroded teeth, and further in vitro and in vivo studies are required.

\section{Conclusion}

It was concluded that the use of aluminum oxide sandblasting and aluminum oxide discs did not positively increase the bond strength of brackets when bonded to artificially eroded enamel. However, the Adhesive Remnant Index showed that teeth artificially eroded with cola drinks present higher resin adhesion to enamel.

\section{Acknowledgments}

The authors would like to thank FAPITEC/SE (Foundation for Research and Technological Innovation Support of the State of Sergipe) and CAPES (Coordination for the Improvement of Higher Education Personnel) for funding the execution of this work through PROMOB. 


\section{References}

Ahrari, F., Basafa, M., Fekrazad, R., Mokarram, M., \& Akbari, M. (2012). The efficacy of Er,Cr:YSGG laser in reconditioning of metallic orthodontic brackets. Photomedicine and laser surgery, 30(1), 41-46. https://doi.org/10.1089/pho.2011.3088

Al Maaitah, E. F., Alomari, S., Abu Alhaija, E. S., \& Saf, A. A. (2013). The effect of different bracket base cleaning method on shear bond strength of rebonded brackets. The journal of contemporary dental practice, 14(5), 866-870. https://doi.org/10.5005/jp-journals-10024-1417

Anita P. \& Kailasam V. (2021). Effect of sandblasting on the shear bond strength of recycled metal brackets: A systematic review and meta-analysis of invitro studies. International Orthodontics, ISSN 1761-7227, https://doi.org/10.1016/j.ortho.2021.05.007.

Barbour, M. E., Parker, D. M., Allen, G. C., \& Jandt, K. D. (2005). Human enamel erosion in constant composition citric acid solutions as a function of degree of saturation with respect to hydroxyapatite. Journal of oral rehabilitation, 32(1), 16-21. https://doi.org/10.1111/j.1365-2842.2004.01365.x

Basudan, A. M., \& Al-Emran, S. E. (2001). The effects of in-office reconditioning on the morphology of slots and bases of stainless steel brackets and on the shear/peel bond strength. Journal of orthodontics, 28(3), 231-236. https://doi.org/10.1093/ortho/28.3.231

Buchman D. J. (1980). Effects of recycling on metallic direct-bond orthodontic brackets. American journal of orthodontics, 77(6), 654-668. https://doi.org/10.1016/0002-9416(80)90157-8

Casas-Apayco L. C, Dreibi V. M, Hipólito A. C, Graeff M. S. Z, Rios D, Magalhães A. C, Buzalaf M. A. R, \& Wang L. (2014) Erosive cola-based drinks affect the bonding to enamel surface: an in vitro study. J Appl Oral Sci., 22(5), 434-41.

Deery, C., Wagner, M. L., Longbottom, C., Simon, R., \& Nugent, Z. J. (2000). The prevalence of dental erosion in a United States and a United Kingdom sample of adolescents. Pediatric dentistry, 22(6), 505-510.

Eminkahyagil, N., Arman, A., Cetinșahin, A., \& Karabulut, E. (2006). Effect of resin-removal methods on enamel and shear bond strength of rebonded brackets. The Angle orthodontist, 76(2), 314-321. https://doi.org/10.1043/0003-3219(2006)076[0314:EORMOE]2.0.CO;2

Federlin, M., Thonemann, B., Schmalz, G., \& Urlinger, T. (1998). Clinical evaluation of different adhesive systems for restoring teeth with erosion lesions. Clinical oral investigations, 2(2), 58-66. https://doi.org/10.1007/s007840050046

Ganss, C., Klimek, J., \& Giese, K. (2001). Dental erosion in children and adolescents--a cross-sectional and longitudinal investigation using study models Community dentistry and oral epidemiology, 29(4), 264-271. https://doi.org/10.1034/j.1600-0528.2001.290405.x

Gedalia, I., Ionat-Bendat, D., Ben-Mosheh, S., \& Shapira, L. (1991). Tooth enamel softening with a cola type drink and rehardening with hard cheese or stimulated saliva in situ. Journal of oral rehabilitation, 18(6), 501-506. https://doi.org/10.1111/j.1365-2842.1991.tb00072.x

Gupta, N., Kumar, D., \& Palla, A. (2017). Evaluation of the effect of three innovative recyling methods on the shear bond strength of stainless steel bracketsan in vitro study. Journal of clinical and experimental dentistry, 9(4), e550-e555. https://doi.org/10.4317/jced.53586

Hall, A. F., Buchanan, C. A., Millett, D. T., Creanor, S. L., Strang, R., \& Foye, R. H. (1999). The effect of saliva on enamel and dentine erosion. Journal of dentistry, 27(5), 333-339. https://doi.org/10.1016/s0300-5712(98)00067-0

Katona, T. R., \& Long, R. W. (2006). Effect of loading mode on bond strength of orthodontic brackets bonded with 2 systems. American journal of orthodontics and dentofacial orthopedics: official publication of the American Association of Orthodontists, its constituent societies, and the American Board of Orthodontics, 129(1), 60-64. https://doi.org/10.1016/j.ajodo.2004.09.020

Klocke, A., \& Kahl-Nieke, B. (2005). Influence of cross-head speed in orthodontic bond strength testing. Dental materials: official publication of the Academy of Dental Materials, 21(2), 139-144. https://doi.org/10.1016/j.dental.2004.03.004

Lussi, A., Jaeggi, T., \& Zero, D. (2004). The role of diet in the aetiology of dental erosion. Caries research,38 Suppl 1, 34-44. https://doi.org/10.1159/000074360

Magalhães, A. C., Wiegand, A., Rios, D., Honório, H. M., \& Buzalaf, M. A. (2009). Insights into preventive measures for dental erosion. Journal of applied oral science: revista FOB, 17(2), 75-86. https://doi.org/10.1590/s1678-77572009000200002

Meira, I. A., Dos Santos, E. J., Fernandes, N. L., de Sousa, E. T., de Oliveira, A. F., \& Sampaio, F. C. (2021). Erosive effect of industrialized fruit juices exposure in enamel and dentine substrates: An in vitro study. Journal of clinical and experimental dentistry, 13(1), e48-e55. https://doi.org/10.4317/jced.57385

Meurman, J. H., \& Ten Cate, J. M. (1996). Pathogenesis and modifying factors of dental erosion. European journal of oral sciences, 104(2), 199-206. https://doi.org/10.1111/j.1600-0722.1996.tb00068.x

Mine, A., De Munck, J., Cardoso, M. V., Van Landuyt, K. L., Poitevin, A., Kuboki, T., Yoshida, Y., Suzuki, K. \& Van Meerbeek, B. (2010). Enamel-smear compromises bonding by mild self-etch adhesives. J Dent Res, 89(12), 1505-9.

Mitchell L. (1992). Decalcification during orthodontic treatment with fixed appliances--an overview. British journal of orthodontics, 19(3), 199-205. https://doi.org/10.1179/bjo.19.3.199

Montero, M. M., Vicente, A., Alfonso-Hernández, N., Jiménez-López, M., \& Bravo-González, L. A. (2015). Comparison of shear bond strength of brackets recycled using micro sandblasting and industrial methods. The Angle orthodontist, 85(3), 461-467. https://doi.org/10.2319/032414-221.1

Moura, S. R. B. d. M., Carmo, A. C. M. d., \& Tavano, O. L. (2020). Uma reflexão sobre metodologias in vitro para estimativa de índice glicêmico de alimentos. Research, Society and Development, 9(10). https://doi.org/10.33448/rsd-v9i10.8572 
Research, Society and Development, v. 10, n. 13, e34101320132, 2021

(CC BY 4.0) | ISSN 2525-3409 | DOI: http://dx.doi.org/10.33448/rsd-v10i13.20132

Oncag, G., Tuncer, A. V., \& Tosun, Y. S. (2005). Acidic soft drinks effects on the shear bond strength of orthodontic brackets and a scanning electron microscopy evaluation of the enamel. The Angle orthodontist, 75(2), 247-253. https://doi.org/10.1043/0003-3219(2005)075<0243:ASDEOT>2.0.CO;2

Pasha, A., Sindhu, D., Nayak, R. S., Mamatha, J., Chaitra, K. R., \& Vishwakarma, S. (2015). The Effect of Two Soft Drinks on Bracket Bond Strength and on Intact and Sealed Enamel: An In Vitro Study. Journal of international oral health: JIOH, 7(Suppl 2), 26-33.

Pashley, D. H., Tay, F. R., Breschi, L., Tjäderhane, L., Carvalho, R. M., Carrilho, M., \& Tezvergil-Mutluay, A. (2011). State of the art etch-and-rinse adhesives. Dental materials: official publication of the Academy of Dental Materials, 27(1), 1-16. https://doi.org/10.1016/j.dental.2010.10.016

Pereira, A. S., Shitsuka, D. M., Parreira, F. J., \& Shitsuka, R. (2018). Metodologia da pesquisa científica (1a ed..). Santa Maria: Núcleo de Tecnologia Educacional da Universidade Federal de Santa Maria. ISBN no 978-85-8341-204-5.

Reddy, Y. N., Varma, D. P., Kumar, A. G., Kumar, K. V., \& Shetty, S. V. (2011). Effect of thermal recycling of metal brackets on shear and tensile bond strength. The journal of contemporary dental practice, 12(4), 287-294. https://doi.org/10.5005/jp-journals-10024-1048

Rios, D. (2004). Avaliação "in situ" do efeito erosivo de um refrigerante, associado ou não à escovação e ação salivar, em dentes humanos e bovinos. Tese de Doutorado, Universidade de São Paulo, Bauru, SP, Brasil.

Talbot, T. Q., Blankenau, R. J., Zobitz, M. E., Weaver, A. L., Lohse, C. M., \& Rebellato, J. (2000). Effect of argon laser irradiation on shear bond strength of orthodontic brackets: an in vitro study. American journal of orthodontics and dentofacial orthopedics: official publication of the American Association of Orthodontists, its constituent societies, and the American Board of Orthodontics, 118(3), 274-279. https://doi.org/10.1067/mod.2000.106069

Tavares, S. W., Consani, S., Nouer, D. F., Magnani, M. B. B. A., Pereira Neto, J. S. \& Romano, F. L. (2003). Evaluation in vitro of the shear bond strength of aluminum oxide recycled brackets. Braz J Oral Sci, 378-381.

Tavares, S. W., Consani, S., Nouer, D. F., Magnani, M. B., Nouer, P. R., \& Martins, L. M. (2006). Shear bond strength of new and recycled brackets to enamel. Brazilian dental journal, 17(1), 44-48. https://doi.org/10.1590/s0103-64402006000100010

Wang, X., \& Lussi, A. (2010). Assessment and management of dental erosion. Dental clinics of North America, 54(3), 565-578. https://doi.org/10.1016/j.cden.2010.03.003

Yassaei, S., Aghili, H., KhanPayeh, E., \& Goldani Moghadam, M. (2014). Comparison of shear bond strength of rebonded brackets with four methods of adhesive removal. Lasers Med Sci., 29(5), 1563-8. 10.1007/s10103-013-1310-9. 